\title{
R Factor-mediated Resistance to Ultraviolet Light in Strains of Escherichia coli Deficient in Known Repair Functions
}

\author{
By D. J. TWEATS*, MARGARET J. THOMPSON†, \\ R. J. PINNEY AND J. T. SMITH \\ Microbiology Section, Department of Pharmaceutics, The School of Pharmacy, \\ University of London, London $W C_{1} N$ I $A X$
}

(Received 4 July 1975)

\begin{abstract}
SUMMARY
The expression of resistance to u.v. irradiation mediated by $\mathrm{R}$ factor $\mathrm{R} 46$ has been studied in strains deficient in excision repair and recombination repair. The $\mathbf{R}$ factor protected wild-type bacteria and also wild-type cells in which repair had been inhibited by the substitution of bromouracil for chromosomal thymine. It increased the survival of strains defective in the endonucleolytic (uvr), repolymerizing ( $p o l)$ and joining (lig) stages of the excision repair process. Recombination deficient bacteria mutant at the $\operatorname{rec} B$ or $\operatorname{rec} C$ loci were protected by $\mathrm{R} 46$, but the $\mathrm{R}$ factor had little effect on the survival of a recA strain or a $\operatorname{rec} A$ rec $B$ double mutant. R46 increased the survival of cells that had been treated with chloramphenicol before u.v. irradiation, but did not protect cultures treated with chloramphenicol after irradiation. It is concluded that $\mathrm{R} 46$ confers resistance to the lethal effects of u.v. irradiation by a mechanism that is independent of excision repair. Resistance appears to be mediated by an inducible gene product, which is possibly a nuclease and dependent on a functional host $\operatorname{rec} A$ gene for expression.
\end{abstract}

\section{INTRODUCTION}

A number of plasmids confer resistance to the lethal effects of u.v. irradiation on wild-type bacteria (Howarth, I965; Drabble \& Stocker, 1968; Marsh \& Smith, 1969). These include the $\mathrm{fi}^{-} \mathrm{N}$ group $\mathrm{R}$ factor $\mathrm{R} 46$, which has also been designated R-Brighton (Anderson \& Datta, I965), RI8I8 (Datta \& Kontomichalou, I965) and TPI20 (Grindley, Grindley \& Anderson, I972). It has been suggested that this u.v. protection may result from the participation of plasmid-borne gene products in the repair of the damaged host genome (Howarth, 1965; Marsh \& Smith, 1969; Siccardi, 1969). To investigate possible interactions of such genes with host DNA repair pathways, we studied the effects of R46 on the u.v. sensitivity of Escherichia coli strains that are deficient in excision repair (Setlow \& Carrier, 1964; Boyce \& Howard-Flanders, 1964) and recombination repair (Rupp \& Howard-Flanders, 1968).

A preliminary report of some of this work has been published (Tweats $e t a l$., $1974 b$ ).

* Present address: Genetics Department, University College of Swansea, Singleton Park, Swansea.

$\dagger$ Present address: Distillers Company Ltd, Glenochil Technical Centre, Menstrie, Clackmannanshire. 
Table I. Properties of E. coli strains used

\begin{tabular}{|c|c|c|c|}
\hline Strain & Genotype & Source & Reference \\
\hline NIO7I* & lac galE galK trp tsx & M. Gellert & Gellert \& Bullock ( 1970 ) \\
\hline ABI 886 & $\begin{array}{l}\text { pro ara arg his leu thr lac thi tsx } \\
\text { gal xyl mtl uvrA6 }\end{array}$ & N. Willetts & $\begin{array}{l}\text { Boyce \& Howard-Flanders } \\
\text { (1964) }\end{array}$ \\
\hline JG I 38 & rha lac thy polAI & Marion Monk & $\begin{array}{l}\text { Monk, Peacey \& Gross } \\
\text { (197I) }\end{array}$ \\
\hline NI 252 & $\begin{array}{l}\text { As Ni071, but also bio thi lop-8 } \\
\text { lig-2 }\end{array}$ & M. Gellert & Gellert \& Bullock (1970) \\
\hline $\mathrm{AB} 2463$ & $\begin{array}{l}\text { pro his arg thi thr leu lac gat } \\
\text { ara xyl mtl tsx recA13 }\end{array}$ & N. Willetts & $\begin{array}{l}\text { Howard-Flanders, Boyce \& } \\
\text { Theriot (1966) }\end{array}$ \\
\hline AB2470 & $\begin{array}{l}\text { pro his arg thi thr leu lac gal } \\
\text { ara xyl mtl tsx recB2I }\end{array}$ & N. Willetts & Howard-Flanders et al. (1966) \\
\hline JC5495 & $\begin{array}{l}\text { ara arg his leu thr lac thi tsx } \\
\text { gal xyl mil recAI } 3 \text { recB2I }\end{array}$ & N. Willetts & Willetts \& Clark (1969) \\
\hline $\mathrm{NH} 4 \mathrm{O} 2 \mathrm{I}$ & metA28 arg thi gal ts $x$ recC 22 & P. Barth & - \\
\hline
\end{tabular}

METHODS

Bacteria. All strains used were derivatives of Escherichia coli $\mathrm{KI} 2$. They are listed, together with their genotypes and source, in Table $\mathrm{I}$.

$R$ factor. R46 is a fi- $\mathrm{N}$ group plasmid (Datta \& Hedges, I97I) isolated from a strain first characterized by Professor E. S. Anderson. It confers resistance to ampicillin, streptomycin, sulphonamides and tetracycline.

Media. These have been described (Tweats, Pinney \& Smith, I974a).

Ultraviolet irradiation. Washed, exponential-phase cultures were resuspended to $10^{8}$ viable organisms/ml at $20^{\circ} \mathrm{C}$ in Davis \& Mingioli (1950) salts solution which lacked a carbon source (DM base). The suspension $(2 \mathrm{ml})$ was transferred to a $5 \mathrm{~cm}$ diameter glass Petri dish and irradiated, with stirring, under a Hanovia model 12 low pressure mercury lamp, which emitted light at $254 \mathrm{~nm}$. The lamp was clamped either at $18 \mathrm{~cm}$ above the sample, giving a dose rate of $5.2 \times 10^{-6} \mathrm{~J} / \mathrm{mm}^{2} / \mathrm{s}$, or at $60 \mathrm{~cm}$ above the sample (dose rate of $\mathrm{I} \cdot 4 \times \mathrm{IO}^{-6}$ $\mathrm{J} / \mathrm{mm}^{2} / \mathrm{s}$ ). Dosimetry was determined using a model J-225 Blak-Ray u.v. meter. Viable counts of irradiated suspensions were estimated by dilution in DM base and spreading $0.1 \mathrm{ml}$ samples on to nutrient agar plates. These were incubated overnight at $37^{\circ} \mathrm{C}$. Exposure of irradiated cells to ambient artificial light was minimized to prevent photoreactivation of u.v.-induced damage (Setlow, 1966), as recommended by Marsh \& Smith (1969).

Preparation and u.v. irradiation of cultures grown in bromodeoxyuridine. Thymine-requiring mutants were selected by the method of Stacey \& Simson (1965) and grown overnight in DM medium supplemented with $60 \mu \mathrm{g}$ thyrnine $/ \mathrm{ml}$. These cultures were diluted $\mathrm{I}$ in $\mathrm{I00}$ into DM medium containing $200 \mu \mathrm{g}$ bromodeoxyuridine $(\mathrm{BUdR}) / \mathrm{ml}$ instead of thymine, and incubation was continued for $40 \mathrm{~h}$. The cells were again diluted I in 100 into BUdRcontaining medium and incubated for a further $3 \mathrm{~h}$ before being washed and irradiated as described. Irradiated cultures were diluted in DM base and plated on DM medium containing $60 \mu \mathrm{g}$ thymine $/ \mathrm{ml}$.

Treatment of cultures with chloramphenicol before irradiation. Overnight nutrient broth cultures were diluted $\mathrm{I}$ in $\mathrm{I} 00$ into fresh broth and incubated for $3 \mathrm{~h}$ before chloramphenicol 
was added at a final concentration of $10 \mu \mathrm{g} / \mathrm{ml}$. The cells were incubated for a further $2 \mathrm{~h}$ in the presence of the drug and were then washed and irradiated.

Treatment of cultures with chloramphenicol after irradiation. Exponential-phase cultures were grown and irradiated in the normal manner. Irradiated suspension (I ml) was filtered through a membrane filter (pore size $0.45 \mu \mathrm{m}$ ) and resuspended in $\mathrm{I}$ ml nutrient broth containing Io $\mu \mathrm{g}$ chloramphenicol. Each suspension was incubated for $3 \mathrm{~h}$ before dilution in DMbase and plating on nutrient agar.

\section{RESULTS}

\section{U.ltraviolet protection conferred by $R 46$ on wild-type strains}

R46 confers u.v. resistance on E. coli strain NI07I, which is wild-type with respect to both excision and recombination repair (Fig. I). When repair was inhibited by the substitution of bromouracil for chromosomal thymine (Aoki, Boyce \& Howard-Flanders, 1966; Hanawalt, I968), the $\mathrm{R}$ factor still increased the survival of this wild-type strain after u.v. irradiation (Fig. 2).

\section{Effect of $R 46$ on strains deficient in excision repair}

A functional $u v r A$ gene is necessary for the first, endonucleolytic step in the excision repair process (Boyce \& Howard-Flanders, I964; Braun \& Grossman, 1974) and the E. coli uvrA mutant (strain ABI886) was, as expected, much more sensitive to u.v. light than strain N107I, which is wild-type with respect to excision repair activity (Fig. I). However, R46 conferred u.v. protection on strain ABI 886 as well as on strain NI07I (Fig. I). In strain $\mathrm{ABI} 886$, u.v. protection was apparent as a change in the slope of the survival curve rather than as the production of a shoulder.

The polAI mutant (De Lucia \& Cairns, 1969) is defective in the production of DNA polymerase I, which is necessary for the normal resynthesis of DNA after thymine dimers have been excised (Kornberg, 1969; Glickman, 1974). The u.v. survival curve of the E. coli polAI mutant (strain JGI 38 ) showed a characteristic loss of shoulder (Fig. 3a), but R46 still increased the survival of this strain. Once again the protective effect of R46 was seen as a change in the slope of the survival curve.

Escherichia coli strain NI 252 (Gellert \& Bullock, 1970), which has the genotype lop-8 lig-2, produces excess defective ligase and is therefore deficient in the final step of excision repair (Hanawalt, 1968). R46 also conferred an increased resistance to u.v. light on this strain (Fig. $3 b$ ). Yet again the $\mathrm{R}$ factor-mediated u.v. resistance was apparent as a change in slope of the survival curve, rather than as the production of a shoulder. Recent examination of strains in which the lig mutation has been separated from the Lop phenotype suggests that the original lop lig strains have an enhanced u.v. sensitivity due to a second, distant mutation (Gottesman, Hicks \& Gellert, 1973). However, results (Fig. 4) using a derivative of strain N107I into which only the lig 2 mutation had been transduced showed that R46 still conferred u.v. protection on this ligase-defective strain.

\section{Effect of $R 46$ on strains deficient in recombination repair}

Replication of DNA that contains thymine dimers results in the production of a gap in the daughter strand opposite each dimer (Rupp \& Howard-Flanders, 1968). These gaps are subsequently repaired by a mechanism involving recombination, which in $E$. coli requires the products of at least three cistrons: $\operatorname{rec} A$, $\operatorname{rec} B$ and $\operatorname{rec} C$ (Clark \& Margulies, I965; Howard-Flanders, Boyce \& Theriot, 1966). The rec $A$ gene product appears to have several 


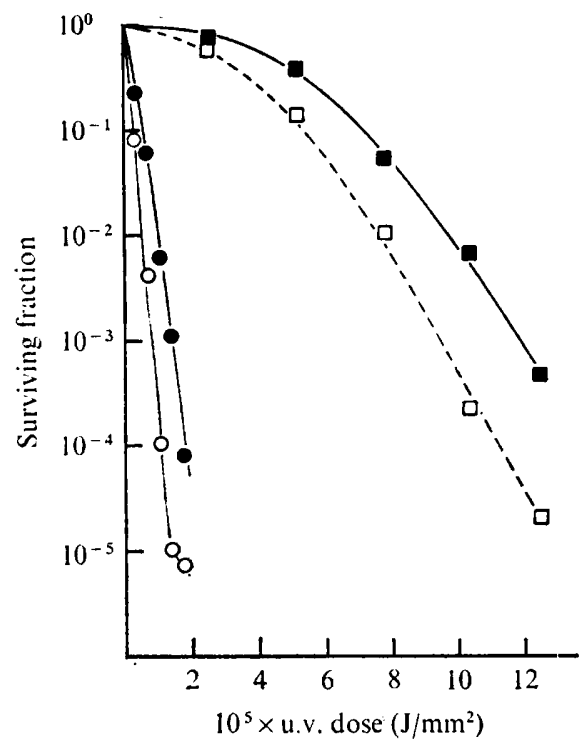

Fig. I

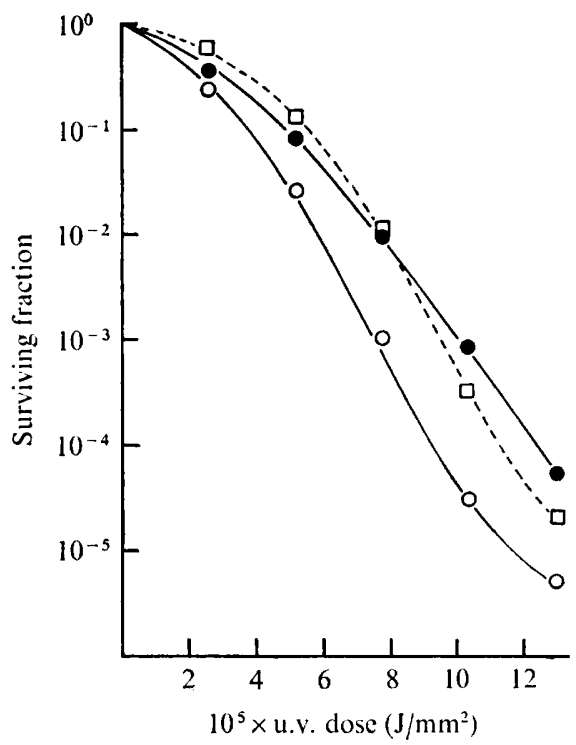

Fig. 2

Fig. I. Ultraviolet protection mediated by R factor R46 on $E$. coli strain NI07I, which is wild-type with respect to u.v. repair, and strain $\mathrm{ABI} 886$, which is $u v r A 6 .--\square--$, NIO7I; $\square$, NIO7I (R46); $\bigcirc$, $A B I 886$;,$A B I 886\left(R_{4} 6\right)$. The broken line for the $R^{-}$strain NIO7I is repeated in all figures as a wildtype control.

Fig. 2. Effect of growth in bromodeoxyuridine (BUdR) on u.v. protection mediated by R46 in a Thy ${ }^{-}$derivative of E. coli strain NI07I. Strain NI07I thy was grown for many generations in a minimal medium in which BUdR had replaced thymine. The cells were then washed and u.v.irradiated as described in Methods. O, NIO7I thy grown in BUdR;, , NIO7I thy (R46) grown in BUdR; -- $\square--$, NI07I thy ${ }^{+}$grown as in Fig. I.

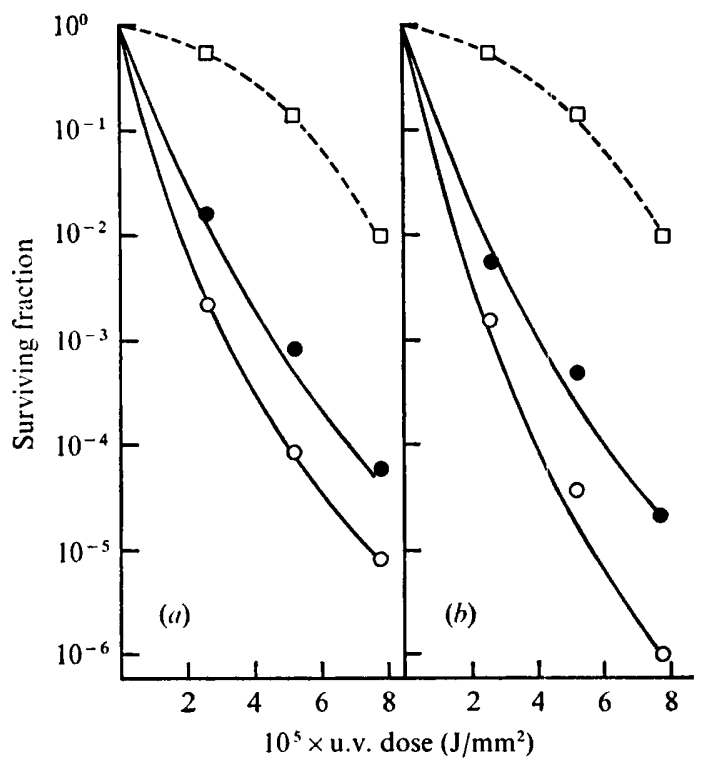

Fig. 3

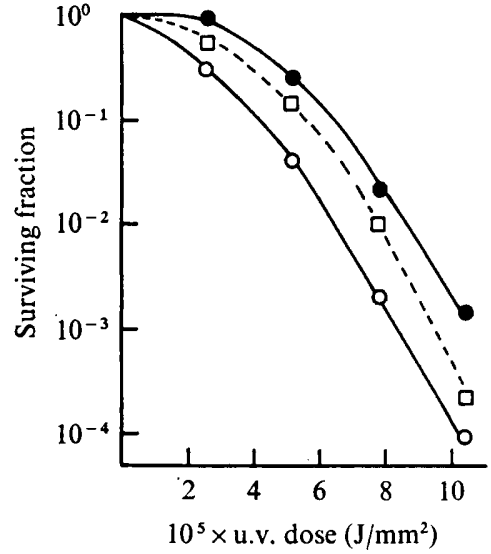

Fig. 4

Fig. 3. Ultraviolet protection conferred by R46 on $(a) E$. coli strain JG 138 polAI and $(b)$ the ligasedefective $E$. coli strain NI 252 lop-8 lig-2. (a): O, JGI38; •, JGI38 (R46). (b) O, NI252; ๑, NI 252 (R46). -- $\square--$, As in Fig. I.

Fig. 4. Ultraviolet protection conferred by R46 on E. coli strain NIO7I lig-2. O, NIO7I lig-2; NI07I lig-2 (R46); -- $\square--$, As in Fig. I. 


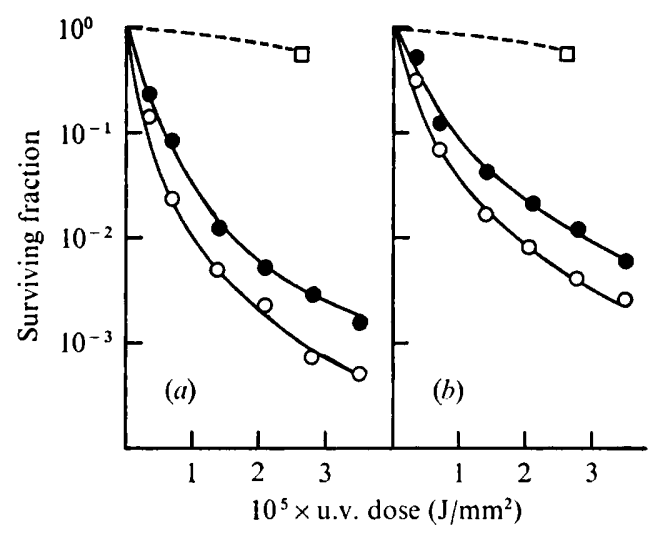

Fig. 5

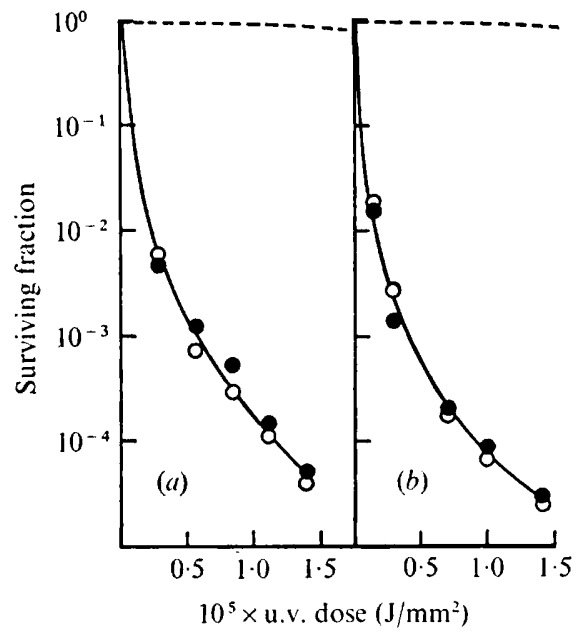

Fig. 6

Fig. 5. Ultraviolet protection mediated by R46 on (a) E. coli strain AB2470 rec B2I and (b) E. coli strain NH402I recC22. (a) $\bigcirc, \mathrm{AB} 2470 \mathrm{recB2I}$;, $\mathrm{AB} 2470 \mathrm{recB2I}(\mathrm{R} 46)$. (b) $\bigcirc$, NH402I recC22; -, NH402I recC22 (R46). - $\square--$, As in Fig. I.

Fig. 6. Effect of $\mathrm{R} 46$ on sensitivity of (a) E. coli strain $\mathrm{AB} 2463$ recAI3 and (b) E. coli strain JC5495 rec $A I 3$ recB2I. (a) $\bigcirc, \mathrm{AB} 2463$; O AB2463 (R46). (b) $\bigcirc$, JC5495; O, JC5495 (R46). Broken line is part of the survival curve for the wild-type strain N107I (see Fig. I).

functions including control of the synthesis of the ATP-dependent nuclease (exonuclease V) determined by the $\operatorname{rec} B$ and $\operatorname{rec} C$ loci (Oishi, 1969; Barbour \& Clark, 1970). R46 still produced an increase in the survival of both the $E$. coli recB mutant (strain AB2470) and the recC mutant (strain NH402I) after u.v. irradiation (Fig. 5). However, the $\mathrm{R}$ factor had little effect on the u.v. resistance of the rec $A$ mutant (strain $\mathrm{AB2463}$ ) or on the $\operatorname{rec} A \operatorname{rec} B$ double mutant (strain JC5495) (Fig. 6).

\section{Effect of inhibition of protein synthesis on $R$ factor-mediated $u . v$. protection}

When the recombination- and excision-proficient strain NI07I was irradiated and then exposed to chloramphenicol, the protective effect of R46 was abolished (Fig. 7). However, the $\mathrm{R}$ factor still protected cells that had been treated with chloramphenicol before irradiation (Fig. 8). This suggests that the $\mathrm{R}$ factor gene product involved in protection is produced in significant quantities only after irradiation, i.e. it is inducible.

\section{DISCUSSION}

R46 protects strain NI07I, which has functional excision and recombination repair pathways. Thus even when excision and recombination are working optimally an extra component of resistance is added by $\mathrm{R} 46$. The $\mathrm{R}$ factor also protects strains in which the excision repair system of the host is defective in any one of its stages, which suggests that the mechanism of u.v. resistance mediated by R46 is totally independent of excision repair.

The interaction of R46 with post-replication recombination repair is more complex. In agreement with the results of similar work by Marsh \& Smith (1969) and MacPhee (1973) who used $\mathrm{R}$ factors other than $\mathrm{R} 46$, it was found that the protective effect was not expressed in a $\operatorname{rec} A$ host, but since it protected $\operatorname{rec} B$ and $\operatorname{rec} C$ strains, it would appear that the u.v. 


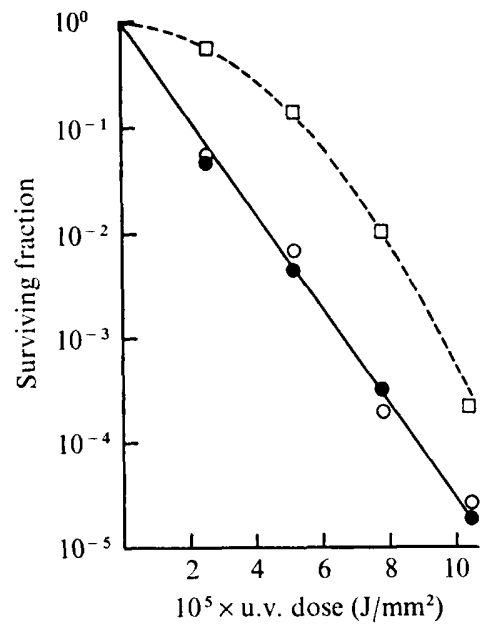

Fig. 7

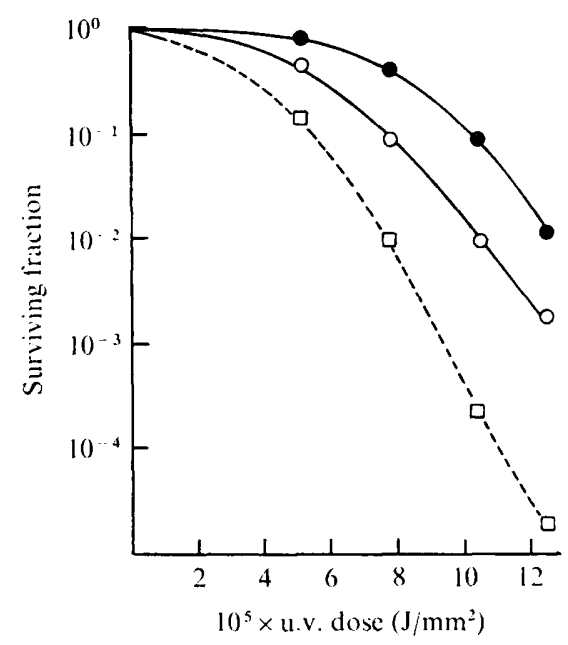

Fig. 8

Fig. 7. Effect of R46 on the survival of $E$. ccli strain N107I treated with chloramphenicol $(\mathrm{Cm})$ after u.v. irradiation. Washed exponential cultures of strain NI07I (O) and NIO7I (R46) (O) were irradiated as described in Methods. They were then resuspended in nutrient broth containing $10 \mu \mathrm{g}$ $\mathrm{Cm} / \mathrm{ml}$. The suspensions were incubated for $3 \mathrm{~h}$ at $37^{\circ} \mathrm{C}$ before plating. -- $\square--$, Survival of strain NI07I without Cm treatment.

Fig. 8. R46-mediated u.v. resistance in E. coli strain N1071 treated with chloramphenicol $(\mathrm{Cm})$ before irradiation. Exponential cultures of strain NI07I (O) and NI07I (R46) (O) were incubated for $2 \mathrm{~h}$ in nutrient broth containing $10 \mu \mathrm{g} \mathrm{Cm} / \mathrm{ml}$. They were then washed and irradiated as described in Methods. -- $\square--$, Survival of strain NIO $7 \mathrm{I}$ without $\mathrm{Cm}$ treatment.

resistance conferred by the $\mathrm{R}$ factor can be expressed in the absence of host-mediated recombination repair. These results suggest that $\mathrm{R} 46$ may partially be able to compensate for absence of the $\operatorname{rec} B C$ nuclease activity.

MacPhee (I974) demonstrated that another N group R factor, R-Utrecht, has an associated polymerizing activity which can functionally complement DNA polymerase I mutants of Salmonella typhimurium in the host cell reactivation of u.v.-damaged phage. This $\mathrm{R}$ factor also confers u.v. resistance on its host (Drabble \& Stocker, I968), which MacPhee (1974) suggested could be due in part to its polymerase activity.

It is possible to interpret the protective effect of $\mathrm{R} 46$ on a polAI mutant as being the result of functional complementation between an R factor-mediated DNA polymerase and the defective host enzyme. However, it becomes difficult to imagine how such an enzyme could also confer resistance on hosts that are defective in both the initial endonucleolytic step in excision repair, such as the $u v r A$ mutant, and in the final sealing part of the process, such as that found with the lig-2 strain. Moreover, the polymerizing activity of R-Utrecht was found in untreated cells, whereas our results with cells that had been exposed to chloramphenicol after irradiation suggest that the u.v. repair function of $R 46$ requires induction. Also, if the u.v. protection conferred by R-Utrecht and R46 is mediated solely via the activity of a DNA polymerase similar to polymerase $\mathrm{I}$, it is not clear why these $\mathrm{R}$ factors do not protect $\operatorname{rec} A$ strains or $\operatorname{rec} A$ rec $B$ double mutants.

Tweats et al. (1974a) showed that R46 determines an inducible nuclease activity, which may be involved in the elimination of the $\mathrm{R}$ factor under conditions of thymine starvation (Pinney \& Smith, 1972; Birks \& Pinney, 1975), and which could be responsible for its u.v. 
protecting effect. The results presented in this paper are, indeed, more consistent with the hypothesis that R46-mediated u.v. resistance is determined by a nuclease activity which, in agreement with the results of Marsh \& Smith (1969), is dependent on a functional host $\operatorname{rec} A$ gene for expression. Since, however, it is apparent in $\operatorname{rec} B$ and $\operatorname{rec} C$ mutants, we suggest that the $\mathrm{R}$ factor gene product may have some positive effect on post-replication sister strand exchange.

\section{REFERENCES}

ANDERson, E. S. \& DatTA, N. (1965). Resistance to penicillins and its transfer in Enterobacteriaceae. Lancet i, 407-409.

Aoki, S., Boyce, R. P. \& Howard-Flanders, P. (1966). Sensitization of Escherichia coli to radiation by bromouracil: excessive post-irradiation breakdown of deoxyribonucleic acid without concomitant synthesis. Nature, London 209, 686-688.

Barbour, S. D. \& Clark, A. J. (1970). Biochemical and genetic studies of recombination proficiency in Escherichia coli. I. Enzymatic activity associated with $\mathrm{recB}^{+}$and $\mathrm{rec} \mathrm{C}^{+}$genes. Proceedings of the National Academy of Sciences of the United States of America 65, 955-961.

Birks, J. H. \& PinNeY, R. J. (1975). Correlation between thymineless elimination and the absence of $h s p$ II (Eco RII) specificity in N-group R factors. Journal of Bacteriology 121, I 208-I 210.

BOyCE, R. P. \& HowARD-Flanders, P. (I964). Release of ultraviolet light-induced thymine dimers from DNA in E. coli K-12. Proceedings of the National Academy of Sciences of the United States of America 5I, 293-300.

Braun, A. \& Grossman, L. (1974). An endonuclease from Escherichia coli that acts preferentially on UVirradiated DNA and is absent from the $u v r A$ and $u v r B$ mutants. Proceedings of the National Academy of Sciences of the United States of America 71, 1838-1842.

Clark, A. J. \& Margulies, A. D. (1965). Isolation and characterization of recombination-deficient mutants of Escherichia coli K I2. Proceedings of the National Academy of Sciences of the United States of America 53, $45 I-459$.

Datta, N. \& Hedges, R. W. (197I ). Compatibility groups among $f^{-}$R factors. Nature, London 234, 222-223.

Datta, N. \& Kontomichalou, P. (1965). Penicillinase synthesis controlled by infectious $R$ factors from Enterobacteriaceae. Nature, London 208, 239-24I.

Davis, B. D. \& Mingioli, E. S. (1950). Mutants of Escherichia coli requiring methionine or vitamin $\mathbf{B}_{12}$. Journal of Bacteriology 60, 17-28.

De LuCIA, P. \& Cairns, J. (1969). Isolation of an E. coli strain with a mutation affecting DNA polymerase. Nature, London 224, I164-1 I 66.

Drabble, W. T. \& Stocker, B. A. D. (1968). R (transmissible drug resistance) factors in Salmonella typhimurium: pattern of transduction by phage $\mathrm{P}_{22}$ and ultraviolet-protection effect. Journal of General Microbiology 53, 109-123.

Gellert, M. \& Bullock, M. L. (1970). DNA ligase mutants of Escherichia coli. Proceedings of the National Academy of Sciences of the United States of America 67, 1580-1587.

Glickman, B. W. (1974). The role of DNA polymerase I in pyrimidine dimer excision and repair replication in Escherichia coli $\mathrm{KI} 2$ following ultraviolet irradiation. Biochimica et biophysica acta 335, I I 5-I 22.

Gottesman, M. M., Hicks, M. L. \& Gellert, M. (1973). Genetics and function of DNA ligase in Escherichia coli. Journal of Molecular Biology 77, $53 \mathrm{I}-547$.

GrindLey, N. D. F., Grindley, J. N. \& ANDERSON, E. S. (1972). R factor compatibility groups. Molecular and General Genetics I19, 287-297.

Hanawalt, P. C. (1968). Cellular recovery from photochemical damage. In Phatophysiology, vol. 4, pp. 203-25I. Edited by A. C. Giese. New York and London: Academic Press.

Howard-Flanders, P., Boyce, R. P.\& Theriot, L. (1966). Three loci in Escherichia coli K-I 2 that control the excision of pyrimidine dimers and certain other mutagen products from DNA. Genetics 53, I I I9-I I 36.

HowARTH, S. (1965). Resistance to the bactericidal effect of ultraviolet radiation conferred on enterobacteria by the colicine factor coll. Journal of General Microbiology 40, 43-55.

KorNBERG, A. (1969). Active centre of DNA polymerase. Science, New York 163, I4IO-I418.

MACPHEE, D. G. (1973). Effect of rec mutations on the ultraviolet protecting and mutation-enhancing properties of the plasmid R-Utrecht in Salmonella typhimurium. Mutation Research 19, 357-359.

MACPHEE, D. G. (1974). DNA polymerase activity determined by the ultraviolet-protecting plasmid, R-Utrecht. Nature, London 25I, 432-434.

MARSh, E. B. \& SMITH, D. H. (I969). R factors improving survival of Escherichia coli K-I 2 after ultraviolet irradiation. Journal of Bacteriology 100, I $28-\mathrm{I} 39$.

Monk, M., Peacey, M. \& Gross, J. D. (1971). Repair of damage induced by ultraviolet light in DNA polymerase-defective Escherichia coli cells. Journal of Molecular Biology 58, 623-630. 
OIsHI, M. (1969). An ATP-dependent deoxyribonuclease from Escherichia coli with a possible role in genetic recombination. Proceedings of the National Academy of Sciences of the United States of America 64, I 292-I 299.

Pinney, R. J. \& Smith, J. T. (1972). R factor elimination during thymine starvation: effects of inhibition of protein synthesis and readdition of thymine. Journal of Bacteriology III, 36I-367.

RupP, W. D. \& Howard-Flanders, P. (1968). Discontinuities in the DNA synthesised in an excisiondefective strain of Escherichia coli following ultraviolet irradiation. Journal of Molecular Biology 3r, 29I-304.

Setlow, R. B. (I966). Cyclobutane-type pyrimidine dimers in polynucleotides. Science, New York $\mathbf{1 5 3}$, 379-386.

Setlow, R. B. \& Carrier, W. L. (I964). The disappearance of thymine dimers from DNA: an errorcorrecting mechanism. Proceedings of the National Academy of Sciences of the United States of America 5I, 226-23I.

SicCARDI, A. G. (1969). Effects of R factors and other plasmids on ultraviolet susceptibility and host cell reactivation property of Escherichia coli. Journal of Bacteriology 100, 337-346.

StaceY, K. A. \& Simson, E. (1965). Improved method for the isolation of thymine requiring mutants of Escherichia coli. Journal of Bacteriology 90, 554-555.

Tweats, D. J., PINNey, R. J. \& SMITH, J. T. (1974a). R-factor-mediated nuclease activity involved in thymineless elimination. Journal of Bacteriology $118,790-795$.

Tweats, D. J., Pinney, R. J., Thompson, M. \& Smith, J. T. (1974b). R-factor mediated resistance to ultraviolet light. Journal of Pharmacy and Pharmacology 26, 97 P-98P.

Willetts, N. S. \& Clark, A. J. (I969). Characteristics of some multiply recombination-deficient strains of Escherichia coli. Journal of Bacteriology 100, $231-239$. 